AGENDA : Analisis Gender dan Agama , Vol. 3 (1), 2021, (Juni)

\title{
REASON OF INCREASING CASES OF MARRIAGE DISPENSATION AGAINST WOMEN'S RIGHTS
}

\author{
Nailur Rahmi \\ IAIN Batusangkar \\ E-mail: nailurrahmi@iainbatusangkar.ac.id
}

\section{Elimartati}

IAIN Batusangkar

E-mail: elimartati@iainbatusangkar.ac.id

\begin{abstract}
The purposes of this study are to find out and to analyze causes of the increasing cases of marital dispensation on women's right. Field research with normative juridical research are used. It was done by examining several decisions on marital dispensation cases at Batusangkar Religious Court. Data source are derived from the ones who conducted marital dispensation during interview session, and secondary data are from various literature review such as related books and journals. The results reflect causes of the increasing cases of marital dispensation is promiscuity, adultery, already having children, economic factors and poverty. The causes of the increasing cases of marital dispensation has an impact on the rights of women in the reproductive sector, because they are married at a young age. Therefore, the marriage dispensation regulation needs to be reviewed because it has not caused a deterrent effect by imposing sanctions on the person who conducted marital dispensation.
\end{abstract}

Keywords: Dispensation, Women's Rights, Marriage.

\section{PENDAHULUAN:}

Pergeseran sosial dan kebiasaan pacaran masyarakat yang semakin terbuka megakibatkan banyakanya kasus hamil di luar perkawinan. Para remaja menganggap pentingya sebuah pacaran, bahkan tidak hanya untuk mengenal pribadi pasangannya namun mereka cenderung menjadikan masamasa pacaran sebagai uji coba, maupun senang-senang belaka. Hal ini terlihat dari maraknya remaja yang selalu gonta-ganti pasangan, dan masa pacaran yang cenderung tidak lama. Akibat dari pergaulan bebas tersebut, tidak jarang menimbulkan kehamilan sebelum perkawinan. Praktek yang terjadi dari perkawinan pada usia muda atau di bawah umur banyak mendapat masalah dikemudian hari yang pasti akan dijumpai oleh pasangan yang sudah berumah tangga, padahal perkawinan yang sukses membutuhkan kedewasaan tanggung jawab secara fisik maupun mental, untuk bisa mewujudkan harapan yang ideal dalam kehidupan dirumah tangga. Namun tidak dapat di pungkiri bahwa tidak semua perkawinan di usia muda berdampak kurang baik bagi sebuah 
keluarga karena sedikit dari mareka yang telah melangsungkan perkawinan di usia muda dapat mempertahankan dan memelihara keutuhanya sesuai dengan dengan tujuan dari perkawinan itu sendiri. Sebenarnya untuk mendorong agar orang melangsungkan perkawinan di atas batas umur terendah, Undang-Undang No.1 Tahun 1974 tentang perkawinan Pasal 6 ayat (2) telah mengaturnya dengan berbunyi: "untuk melangsungkan perkawinan seorang belum mencapai umur 21 Tahun harus mendapat izin kedua orang tua".1

Djamillah, Reni Kartikawati, menyatakan, adapun akibat dari perkawinan di bawah umur adalah anak perempuan yang perkawinan pada usia muda berpotensi mengalami kehamilan yang beresiko tinggi, dampak atau akibat lainya yang dirasakan oleh anak perempuan yang perkawinan di usia muda adalah adanya ancaman kesehatan mental, anak perempuan sering kali mengalami stres ketika meninggalkan keluarganya dan bertanggung jawab atas keluarganya sendiri, selain itu, perkawinan anak yang di bawah umur juga membawa dampak buruk bagi anak perempuan seperti rentan KDRT. Gejala-gejala dan akibat atau dampak dari perkawinan di bawah umur di atas akan menjadi suatu masalah yang semakin rumi bagi siswa jika tidak segera ditangani. 2

Data yang tercatat di Pengadilan Agama Batusangkar, penulis berhasil

1 Abdul Majid Mahmud Mathlub.. Panduan Hukum Islam Keluaraga Sakinah. (Solo: Era Intermedia, 2005), h. 9

2. Maria Kabang, Eli Trisnowati, Tri Mega Ralasari S. Pemahaman Tentang Akibat Perkawinan Di Bawah Umur Melalui Layanan Informasi Dengan Teknik Diskusi : Jurnal, Vol 4 . 2008, h, 2-4 mengelompokan data dua bulan sebelum dan sesudah Undang-Undang Nomor 16 Tahun 2019 disahkan tepat pada tanggal 15 Oktober 2019. Berikut adalah data Dispensasi perkawinan dua bulan sebelum dan sesudah Undang-Undang Nomor 16 Tahun 2019 disahkan :

Tabel 1.1

\section{Data Pra Undang-Undang Nomor} 16 Tahun 2019 di undangkan

\begin{tabular}{|c|c|c|c|c|}
\hline No. & Pemohon & Nomor Perkara & Umur & Tanggal Perkara \\
\hline 1. & A binti T & 94:Pdt.P/2019/PA.Bsk & 18 Tahun 4 bulan & 09 0ktober 2019 \\
\hline 2. & G binti T & 93Pdt.P/2019PA.Bsk & 18 Tahun 2 bulan & 09 Oktober 2019 \\
\hline 3. & M binti N & 89:Pdt.P/2019PA.Bsk & 15 Tahun 5 bulan & 17 September 2019 \\
\hline
\end{tabular}

Tabel 1.2

Data Pasca Undang-Undang Nomor 16 Tahun 2019 di undangkan

\begin{tabular}{|c|c|c|c|c|}
\hline No. & Pemohon & Nomor perkara & Umur & Tanggal perkara \\
\hline 1. & $\mathrm{x}$ & 96/Pdt.P/2019/PA.Bsk & 18 Tahun 2 bulan & 17 Oktober 2019 \\
\hline 2. & F binti A & 97/Pdt.P/2019/PA.Bsk & 17 Tahun 9 bulan & 17 Oktober 2019 \\
\hline 3. & A binti B & 98/Pdt.P/2019/PA.Bsk & 17 Tahun & 23 Oktober 2019 \\
\hline 4. & A binti A & 99/Pdt.P/2019/PA.Bsk & 17 Tahun 4 bulan & 23 Oktober 2019 \\
\hline 5. & R binti S & 104/Pdt.P/2019/PA.Bdk & 17 Tahun 3 bulan & 12 November 2019 \\
\hline 6. & P binti W & 107/Pdt.P/2019/PA.Bdk & 17 Tahun 11 bulan & 21 November 2019 \\
\hline 7. & $B \operatorname{bin} M$ & 109/Pdt.P/2019/PA.Bdk & 17 Tahun & 22 November 2019 \\
\hline 8. & S binti M & 110/Pdt.P/2019/PA.Bdk & 17 Tahun 1 bulan & 22 November 2019 \\
\hline 9 & P binti B & 111/Pdt.P/2019/PA.Bdk & 17 Tahun 11 bulan & 04 Desember 2019 \\
\hline 10. & D binti S & 112/Pdt.P/2019/PA.Bd & 18 Tahun & 11 Desember 2019 \\
\hline
\end{tabular}

(Sumber data: Pengadilan Agama Batusangkar Tahun 2019)

Berdasarkan data di atas nampak bahwa, terjadi peningkatan kasus dispensasi perkawinan sebelum Undang - Undang No. 16 tahun 2019 diundangkan dibandingkan dengan kasus dispensasi sebelum diundangkannya Undang -Undang No. 16 Tahun 2019. Hal ini membuktikan bahwa penyamaan batas usia minimal perkawinan antara laki-laki dan perempuan tidak bisa mengurangi 
terjadinya pernikahan di usia dini. Hal ini disebabkan karena Undang-Undang masih memberi kesempatan kepada para pihak untuk mengajukan kasus dispensasi perkawinan ke Pengadilan Agama.

Dalam hal ini pemerintah menyerahkan sepenuhnya kasus dispensasi perkawinan kepada Pengadilan Agama. Hakim Pengadilan Agama sebagai pemegang otoritas dalam memutus perkara harus berijtihad seadil mungkin untuk memutus perkara dispensasi perkawinan. keadilan tersebut setidaknya dirasakan oleh semua pihak, sehingga dispensasi perkawinan benarbenar memberikan kemaslahatan bagi semua pihak, bukan satu pihak saja. Hakim dalam menetapkan hukum khususnya dispensasi perkawinan memerlukan pertimbangan yuridis maupun sosiologis dalam menyelesaikan perkara. Agar dapat menentukan keputusan yang nantinya tidak memperburuk keadaan keluaraga pemohon dan keluaraga kedepannya.

Menelusuri fenomena meningkatnya kasus disepensasi perkawinan tersebut maka penulis akan mengkaji lebih dalam tentang apa saja penyebab terjadinya peningkatan kasus disepnsasi perkawinan pasca disyahkannya Undang-Undang Nomor 16 Tahun 2019, dan bagimana analisis tentang dispensasi perkawinan terhadap hak perempuan.

\section{Kerangka Teori}

\section{Batas Usia Perkawinan}

a. Batas Usia Perkawinan Menurut Undang-Undang

Undang-Undang Nomor 1 tahun 1974 pasal 7 ayat (1) tentang perkawinan disebutkan bahwa kedewasaan seorang anak adalah jika laki-laki berumur 21 tahun dan perempuan berumur 18 tahun. Di dalam pasal 7 ayat (1) UndangUndang Nomor 1 tahun 1974 tentang perkawinan disebutkan perkawinan diizinkan jika pria sudah sudah mencapai umur 19 tahun dan wanita telah mencapai umur 16 tahun. Artinya, UndangUndang ini membolehkan anak yang belum dewasa untuk melangsungkan perkawinan. Disisi lain, Undang-Undang terlihat mengakui pelanggaran terhadap ketentuan batas umur dan kematangan calon untuk melangsungkan perkawinan. Hal ini diakomodir dalam pasal 7 ayat (2) UU No. 1 tahun 1974, bahwa pengadilan ataupun pejabat lain yang ditunjuk oleh kedua orangtua dari pihak laki-laki maupun perepmpuan dapat memberikan dispensasi kepada anak di bawah umur untuk melangsungkan perkawinan ketidakkonsistenan UU No. 1 tahun 1974 tentang batas umur perkawinan dapat dimaknai dengan sebagai akomodisasi perkawinan di bawah umur. Apalagi didalam pasal 7 UU tersebut maupun dalam penjelasannya tidak disebutkan alasan yang dapat dija mudah memperolehnya. Ketetapan Undang-Undang sangat longgar, padahal jika ditinjau dari berbagai aspek, banyak kemudharatan yang di timbulkan akibat perkawinan anak di bawah umur, terutama bagi perempuan.

Masalah penentuan umur dalam Undang-Undang perkawinan maupun dalam kompilasi, memang bersifat ijtihadiyah, sebagai usaha pembaharuan pemikiran fiqih yang lalu. 
b. Batas usia perkawinan menurut fiqih

Ayat-ayat tentang perkawinan dalam Alqur'an terdapat 23 ayat. Tapi tidak ada ayat satu pun yang menjelaskan batasan usia perkawinan. Namun jika diteliti lebih lanjut, ayat yang berkaitan dengan kelayakan seseorang untuk perkawinan ada dua ayat dalm Alqur'an, yaitu surat al-Nur (24): 32:

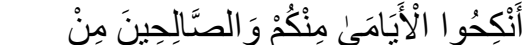

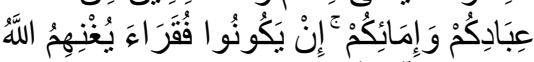

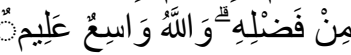
"dan perkawinankanlah orangorang sendirian diantara kamu, dan orang-orang yang layak (berperkawinan) dari hamba hamba sahayamu yang laki-laki dan hamba sahayamu yang perempuan, jika mereka miskin Allah akan menampakan mereka dengan karunianya. Dan Allah Maha Luas pemberiannya lagi Maha Mengetahui. (Q.S An-Nur : 32).

Dalam Tafsir Ibnu Katsir dijelaskan bahwa ayat ini adalah sebuah perintah untuk perkawinan sebagaimana pendapat sebagian dari ulama mewajibkan perkawinan bagi mereka yang mampu.3.

Al-Maraghy menafsirkan sebagaimana yang dikutip oleh mustofa, kalimat washalihin, para laki-laki atau perempuan yang mampu untuk perkawinan dan menjalankan hak-hak suami istri, seperti berbadan sehat, mempunyai harta dan lain-lain. Quraish shihab menafsir kan ayat tersebut "washalihin"., yaitu seorang yang mampu secara mental dan spiritual untuk membina rumah tangga,

3 Al-Damasqy.Tafsir Ibnu Katsir. (Bayrut: Dar AlKutub Al-Ilmiyyah. 2004), h. 269 bukan berarti yang taat beragama, karena fungsi perkawinan memerlukan persiapan bukan hanya materi, tetapi juga persiapan mental maupun spiritual, baik bagi calon laki-laki maupun calon perempuan.4

2. Pengertian Dispensasi perkawinan

Dispensasi perkawinan adalah dispensasi yang diberikan Pengadilan Agama kepada calon mempelai yang belum cukup umur untuk melangsungkan perkawinan, dispensasi kawin diajukan oleh para pihak kepada Pengadilan Agama yang ditunjuk oleh orang tua masing-masing. pengajuan perkara permohonan diajukan dalam bentuk permohonan (Voluntair), dan jika bukan gugatan dan jika calon sumaiistri beragama non-muslim, maka pengajuan permohonannya ke Pengadilan Negeri.5

Menurut Roihan A. Rasyid, dispensasi perkawinan adalah dispensasi yang diberikan Pengadilan Agama kepada calon mempelai yang belum cukup umur untuk melangsungkan perkawinan, bagi pria dan wanita yang belum mencapai 19 (sembilan belas ) tahun. Permohonan dispensasi tersebut diajukan oleh orang tua atau wali calon mempelai pria dan wanita ke Pengadilan Agama daerah setempat. 6

4 Mustofa. Perbandingan Hukum Perkawinan di Dunia Islam. (Bandung: Pustaka Al-Fikris, 2009), h. 22

5 Abdul Jalil. Fenomena Seksualitas Anak Muda, Jurnal, vol 3, 2014, h. 1-3

6 Roihan A. Rasyd. . Hukum Acara Peradilan Agama. (Jakarta: Raja Grafindo persada, 2005), h. 32 
3. Dasar Hukum Dispensasi Perkawinan

Peraturan tentang pelaksanaan perkawinan telah diatur dalam Undang-Undang RI Nomor Tahun 1974 tentang perkawinan. Termasuk diatur tentang syarat-syarat perkawinan, Salah satu syaratnya adalah ditentukannya batas usia untuk melangsungkan Perkawinan, yaitu bagi laki-laki dan perempuan sudah berumur 16 (enam belas) tahun. Jika salah satu dari calon mempelai tidak memenuhi syarat dalam hal usia, maka harus mendapat dispensasi perkawinan dari Pengadilan Agama.

Adapun ketentuan landasan dispensasi perkawinan bagi calon mempelai yang belum mencapai 19 (sembilan belas) tahun bagi laki-laki dan perempuan adalah UndangUndang RI Nomor 16 Tahun 2019 pasal 7 ayat (1) sampai (4) Tentang Perubahan Atas Undang-Undang Nomor 1 Tahun 1974 Tentang Perkawinan.

Ketentuan Pasal 7 diubah sehingga berbunyi sebagai berikut:

1) Perkawinan hanya diizinkan apabila pria dan wanita sudah mencapai umur 19 (sembilan belas) tahun

2) Dalam hal terjadi penyimpangan tehadap ketentuan umur sebagaimana dimaksud pada ayat (1), orang tua pihak wanita dapat diminta dispensasi kepada pengadilan dengan alasan sangat mendesak disertai bukti-bukti pendukung yang cukup.

3) Pemberian dispensasi oleh Pengadilan sebagaimana dimaksud pada ayat (2) wajib mendengarkan pendapat kedua belah pihak calon mempelai yang akan melangsungkan perkawinan.

4) Ketentuan-ketentuan mengenai keadaan seorang atau kedua orang tua calon mempelai sebagaimana dimaksud dalam pasal 6 ayat (3) dan ayat (4) berlaku juga ketentuan mengenai permintaan dispensasi sebagaimana dimaksud pada ayat (2) dengan tidak mengurangi ketentuan sebagaimana dimaksud dalam pasal 6 ayat

\section{METODE:}

Jenis penelitian yang digunakan penelitian field research (studi lapangan), mengungkap dan menggambarkan fenomena data-data yang terjadi dilapangan dengan kenyataan yang sebenarnya dimana peneliti lakukan. Penelitian lapangan dilakukan di Pengadilan Agama Batusangkar tentang Peningkatan Kasus Dispensasi Perkawinan Setelah Undang-Undang Nomor 16 Tahun 2019 Diundangkan memakai jenis penelitian yuridis normatif dengan menggunakan uraian dan informasi yang didapatkan dari objek yang diteliti. Adapaun sumber data terdiri dari sumber data primer dan skunder. Sumber data primer adalah panitera Pengadilan Agama Batusangkar dan pemohon dispensasi perkawinan. Adapun sumber data sekunder adalah dokumen-dokumen penetapan tentang permohonan dispensasi perkawinan tahun 2019 serta karya ilmiah lainya. Teknik Pengumpulan Data yang penulis gunakan adalah wawancara (interview) yaitu, kegiatan 
mengumpulkan data primer yang bersumber langsung dari responden yaitu Panitera Muda Hukum Pengadilan Agama Batusangkar dan Pemohon dispensasi perkawinan. Dalam teknis pelaksanaanya penulis menggunakan wawancara semi terstruktur. Wawancara ini maksudnya adalah peneliti mempersiapkan dulu pertanyaan yang akan diajukan agar informasi yang diperoleh lebih terarah

\section{HASIL DAN PEMBAHASAN: Penyebab Terjadinya Peningkatan Dispensasi Perkawinan}

Dari penelitian yang penulis lakukan di Pengadilan Agama Batusangkar terdapat 10 penetepan permohonan dispensasi perkawinan setelah Undang-Undang Nomor 16 Tahun 2019 diundangkan dan penulis berhasil mengelompokan penyebabpenyebab terjadinya peningkatan kasus dispensasi perkawinan yaitu:

1. Karena pergaulan bebas

Berdasarkan wawancara penulis dengan pemohon dispensasi perkawinan yang bernama B bin B yang mengatakan bahwa alasan Pemohon bermaksud mengajukan permohonan dispensasi perkawinan terhadap anak Pemohon $\mathrm{P}$ binti $\mathrm{B}$ adalah karena anak Pemohon $\mathrm{P}$ binti B dengan seorang laki-laki yang bernama $\mathrm{J}$ bin $\mathrm{Z}$ telah menjalin hubungan percintaan yang sangat dekat dan sulit untuk dipisahkan, dikarenakan anak Pemohon P binti $B$ sering pergi jalan berduaan dengan $\mathrm{J}$ bin $\mathrm{Z}$ keluar rumah, bahkan $\mathrm{J}$ bin $\mathrm{Z}$ sering pergi main ke rumah anak pemohon di Jorong Kandang Melabung, Kenagarian Lawang Mandahiling, Kecamatan Salimpaung, Kabupaten Tanah Datar, dan hubungan tersebut telah berlangsung selama 1 tahun lamanya. Karena dengan saking dekatnya anak pemohon dengan laki-laki tersebut, kemudian pemohon merestui hubungan mereka sampai ke jenjang perkawinan karena dikhawatirkan melakukan perbuatan yang dilarang agama. Dan mengenai UndangUndang 16 Tahun 2019 baik itu dari pihak keluarga wanita maupun lakilaki belum mengetahui terhadap Undang-Undang ini, bahkan yang memberitahukan terhadap UndangUndang ini adalah pencerahan dari KUA.7

2. Karena Zina dan telah punya anak akibat zina

Berdasarkan wawancara penulis dengan pemohon dispensasi perkawinan yang bernama $\mathrm{B}$ bin $\mathrm{M}$ yang mengatakan bahwa alasan Pemohon bermaksud mengajukan permohonan dispensasi perkawinan terhadap anak Pemohon $\mathrm{M}$ bin $\mathrm{B}$ adalah karena anak Pemohon $\mathrm{M}$ bin $\mathrm{B}$ dengan seorang perempuan yang bernama $U$ binti $S$ telah menjalin hubungan percintaan yang sangat dekat dan sulit untuk dipisahkan, dikarenakan anak Pemohon $\mathrm{M}$ bin $\mathrm{B}$ sering pergi jalan berduaan dengan $U$ binti S keluar rumah, bahkan mereka telah melakukan hubungan suami istri, dan sekarang $U$ binti $S$ telah melahirkan seorang anak tanggal 25 Oktober 2019 yang lalu, dan hubungan tersebut telah berlangsung selama 3 tahun lamanya. karena kelakuan anak pemohon yang melakukan perbuatan yang dilarang agama dengan mengingat anak dalam kandungan $\mathrm{U}$ binti $\mathrm{B}$ tersebut maka

7 Pemohon Dispensasi Perkawinan, Wawancara, 28 Juli 2020 
terpaksa pemohon mengajukan dispensasi perkawinan ke Pengadilan Agama Batusangkar. dan juga Pemohon tidak mengetahui terhadap Undang-Undang Nomor 16 tahun 2019 ini, hanya saja diberitahu oleh KUA bahwa usia yang boleh untuk melakukan perkawinan adalah 19 Tahun. Kalau memang ada alasan yang jelas dan terbukti untuk mengajukan dispensasi perkawinan maka boleh diajukan permohonan dispensasi perkawinan ke pengadilan. 8

3. Faktor ekonomi dan kemiskinan

Berdasarkan wawancara penulis dengan pemohon dispensasi perkawinan bahwasanya pemohon bekerja sebagai petani dan istri nya pemohon bekerja sebagai buruh tani di sawah orang lain bahkan pemohon kalau ada modal maka pemohon berjualan sate keliling. Pemohon mempunyai 3 (tiga) orang anak dan anak perempuan yang paling tua itu adalah anak yang mengajukan pemohonan dispensasi perkawinan di Pengadilan Agama Batusangkar. Setelah penulis mewawancarai anak tersebut bahwasanya anak tersebut sudah 2 (dua) kali pindah sekolah sebelum melakukan perkawinan dengan calon suaminya alasannya berhenti sekolah karena orang tuanya tidak bisa membiayainya sekolah dan kebetulan di bawahnya masih ada adik-adiknya yang bersekolah. kalau dilihat alasannya mengajukan permohonan dispensasi perkawinan karena sudah mempunyai hubungan sangat erat dengan calon suaminya

8 Pemohon Dispensasi Perkawinan, Wawancara, 28 Juli 2020 dan untuk mengurangi beban kehidupan orang tuanya. 9

4. Karena pergaulan bebas

Berdasarkan wawancara penulis dengan pemohon dispensasi perkawinan yang bernama B bin B yang mengatakan bahwa alasan Pemohon bermaksud mengajukan permohonan dispensasi perkawinan terhadap anak Pemohon P binti B adalah karena anak Pemohon $\mathrm{P}$ binti B dengan seorang laki-laki yang bernama $\mathrm{J}$ bin $\mathrm{Z}$ telah menjalin hubungan percintaan yang sangat dekat dan sulit untuk dipisahkan, dikarenakan anak Pemohon $\mathrm{P}$ binti $B$ sering pergi jalan berduaan dengan $\mathrm{J}$ bin $\mathrm{Z}$ keluar rumah, bahkan $\mathrm{J}$ bin $\mathrm{Z}$ sering pergi main ke rumah anak pemohon di Jorong Kandang Melabung, Kenagarian Lawang Mandahiling, Kecamatan Salimpaung, Kabupaten Tanah Datar, dan hubungan tersebut telah berlangsung selama 1 tahun lamanya. Karena dengan saking dekatnya anak pemohon dengan laki-laki tersebut, kemudian pemohon merestui hubungan mereka sampai ke jenjang perkawinan karena dikhawatirkan melakukan perbuatan yang dilarang agama. Dan mengenai UndangUndang 16 Tahun 2019 baik itu dari pihak keluarga wanita maupun lakilaki belum mengetahui terhadap Undang-Undang ini, bahkan yang memberitahukan terhadap UndangUndang ini adalah pencerahan dari KUA. 10

\footnotetext{
9 Pemohon Dispensasi Perkawinan, Wawancara, 16 September 2020 10 Pemohon Dispensasi Perkawinan, Wawancara, 28 Juli 2020
} 


\section{Analisis tentang Dispensasi Perkawinan Terhadap Hak Perempuan}

Adanya keyakinan bahwa perkawinan dalam usia anak merupakan cara untuk menyelesaikan problem social mulai dari kemiskinan hingga problem moralitas, menjadi salah satu pemicu bagi tingginya praktik perkawinan anak, terutama bagi anak perempuan. Hal ini perlu dapat perhatian semua pihak agar cara penyelesaian program sosial dengan menempatka anak sebagi objek penderita perlu dikoreksi. Pada kenyataannya, perkawinan usia anak justru secara potensial dapat melahirkan sejumlah persoalan baru ditengah masyarakat. 11

Fenomena perkawinan anak yang marak terjadi di masyarakat Indonesia tentu berkaitan langsung dengan problem sosial. Salah satu yang paling umum adalah faktor kemiskinan. Paradigma yang berkembang di tengah masyarakat bawah dengan latar belakang pendidikan rendah dan ekonomi lemah menikahkan anak pada usia di bawah umur merupakan upaya melepaskan diri dari jerat kemiskinan, karena anak yang sudah menikah tidak lagi menjadi beban orangtuanya. Namun demikian seiring berjalannya waktu, fenomena perkawinan anak nyatanya tidak hanya terjadi dan berkembang di kalangan masyarakat bawah, tapi perkawinan masa muda dan anak juga terjadi di kalangan masyarakat menengah perkotaan. Di kalangan masyarakat kelas menengah perkotaan fenomena perkawinan usia muda lebih sering merupakan ekses negative dari pergaulan bebas. Banyak

11 Bani Syarif Maula, Jurnal Studi Islam Gender dan Anak, IAIN Purwekerto, 2019,14,.1, h. 17 orangtua memutuskan menikahkan anak pada usia muda agar tidak terjebak pada prilaku sek yang bebas, misalnya terjadi kehamilan di luar nikah. Di kalangan masyarakat perkotaan paradigm yang berkembang adalah adanya keyakina bahwa perkawinan di usia muda dapat menjadi solusi untuk menghindarkan anak-anak usia remaja dari pergaulan bebas .12

Meskipun dari segi usia minimal perkawinan sudah disetarakan anatar laki-laki dan perempuan ,tetapi justru menimbulkan dampak baru yaitu meningkatnya kasus dispensasi perkawinan dengan berbagai macam penyebabnya. Jika dilihat dari pelaksanaan dispensai perkawinan di atas ada beberapa hak perempuan yang terabaikan dalam perkawinan di antaranya mendapatkan hak kesehatan reproduksi. Perkawinan di usia dini bisa menmbulkan peluang hamil dan melahirkan anak lebih banyak dan akan berdampak pada kesehatan reproduksi maupun fisik secara umum. Hak-hak reproduksi merupakan bagian dari hak asasi manusia yang diakui oleh hukum nasional, dokumen internasional tentang hak asasi manusia, dan dokumen-dokumen kesepakatan atau perjanjian lainnya. Hak-hak ini menjamin hak-hak dasar setiap pasangan dan individu untuk memutuskan secara bebas dan bertanggung jawab mengenai jumlah, jarak, dan waktu memiliki anak dan untuk memperoleh informasi dan juga terkandung makna memiliki hak untuk mmperoleh standar tertinggi dari kesehatan reproduksi dan seksual. Juga termasuk hak mereka untuk membuat keputusan menyangkut reproduksi

12 Bani Syarif Maula, Jurnal Studi Islam Gender dan Anak, IAIN Purwekerto, 2019,14,.1, h. 20 
yang bebas dari diskriminasi, perlakuan sewenang-wenang, dan kekerasan.

Kosekuensi dari adanya perubahan batas minimal usia perkawinan bagi perempuan yang semula 16 tahun menjadi sama dengan batas minimal usia laki-laki yakni 19 tahun sesuai dengan kategori dewasa adalah perlunya peninjauan ulang atas ketentuan tentang dispensasi perkawinan bagi anak di bawah umur. Ketentuan dispemsasi ini perlu dihilangkan karena dapat menjadi celah bagi masyarakat untuk tetap menikahkan anak-anak mereka sebelum batas waktu yang diperbolehkan oleh aturan perundangundangan. Selain itu ketetntuan batas minimal perlu dipertegas dengan menetapkan sanksi bagi pihak-pihak yang melakukan praktik perkawinan anak di bawah umur, misalnya sanksi bagi wali yang menikahkan, orang yang menjadi saksinya dan mempelai laki-laki dewasa yang menikahi anak di bawah umur.13

Alasan mendesak itu tak bisa sekadar klaim. Harus ada bukti-bukti pendukung yang cukup. Menurut UU Perkawinan yang baru menjelaskan bukti-bukti pendukung yang cukup adalah surat keterangan yang membuktikan bahwa usia mempelai masih di bawah ketentuan undangundang dan surat keterangan dari tenaga kesehatan yang mendukung pernyataan orang tua bahwa perkawinan tersebut sangat mendesak untuk dilaksanakan.

Namun dari sisi lain ketika hakim selalu mengabulkan perkara dispensasi perkawinan dengan alasan hamil duluan, hakim tidak memberikah efek jera

13 Bani Syarif Maula, Jurnal Studi Islam Gender dan Anak, IAIN Purwekerto, 2019,14,.1, h. 33 kepada pelaku. Penulis lebih setuju jika hakim tidak mengabulkan perkara dispensasi nikah dengan berbagai alasan:

a. Untuk memberikan efek jera kepada masyarakat khususnya untuk pelaku pengajuan dispensasi perkawinan agar bisa menjaga dan mengingatkan anaknya terkait pergaulan yang dilakukan oleh anaknya. Dalam hal ini orang tua harus selalu mengawasi pergaulan anak-anaknya.

b. Untuk memberikan pelajaran kepada masyarakat yang belum terjerumus dalam kasus pengajuan dispensasi perkawinan agar tidak meniru pergaulan bebas yang dilakukan oleh pemohon dispensasi perkawinan minimal di hukum dengan cara di proses secara adat dan dibuang sepanjang adat.

c. Memberikan pelajaran kepada Pengadilan Agama Batusangkar dengan Pengadilan Agama yang tidak mengabulkan perkara pengaduan dispensasi perkawinan, maka akan mengurangi perkara dispensasi perkawinan di Pengadilan Agama Batusangkar. Sehingga laju pertumbuhan penduduk dapat dikendalikan, pada kenyataanya bahwa usia yang masih rendah bagi seorang wanita untuk kawin dapat mengakibatkan laju kelahiran dan pertumbuhan penduduk lebih tinggi.

Analisa penulis terhadap permohonan dispensasi perkawinan yang disebabkan faktor ekonomi karena Banyaknya kasus yang terjadi dalam persoalan kemiskinan yang menyebabkan maraknya perkawinan di bawah umur . Ketika orang tua mengalami masalah ekonomi, anak perempuanlah yang dikorbankan, 
kemudian anak tersebut diminta untuk berhenti sekolah untuk sekedar membantu orangtuanya. Menikahkan anak perempuanya, dengan harapan beban hidup mereka akan berkurang. Sayangya, terkadang para gadis ini juga menikah dengan pria berstatus ekonomi tidak jauh beda, sehingga malah menimbulkan kemiskinan baru. Bagi kalangan masyarakat miskin, Perkawinan anaknya merupakan sebuah pelepasan beban. Orang tua akan merasa beban hidupnya berkurang, karena si anak sekarang sudah menjadi tanggung jawab suaminya. Mereka merasa, semakin cepat anak gadisnya perkawinan, semakin baik bagi kehidupan mereka. Bukan karena kebahagiaan si anak, tetapi karena pertimbangan berat ringannya beban hidup yang akan mereka tanggung.

Kalau dilihat dari Dampak positif yang ditimbulkan dari perkawinan dini adalah untuk menghindari hal-hal yang tidak diinginkan seperti perzinahan atau sebagainya. Meskipun perkawinan dini ini tidak dianjurkan oleh islam tetapi perkawinan dini itu diperbolehkan saja asalkan kedua pasangan tersebut sudah ada kesiapan baik itu secara lahir dan batin untuk menikah. Namun adapula dampak negatif dari perkawinan dini diantaranya adalah dalam kesiapan pasangan untuk menjalani hidup bersama, karena dalam pernikahan tidak terlepas dari konflik dan masalah. Dalam perkawinan usia dini ini mereka masih menggunakan emosional dalam menangani konflik atau masalah rumah tanggaya. Menurut penulis mengenai perkawinan dini ini lebih banyak dampak negatifnya dari dampak dampak positifnya karena anak-anak masih di bawah umur tersebut belum saatnya memikirkan perkawinan melainkan memikirkan pendidikan yang lebih tinggi dan membahagiakan orang tuanya dengan prestasi-prestasi yang baik, untuk itu peran orang tua sangat dibutuhkan untuk menumbuhkan kesadaran anak-anaknya terhadap hukum agar terhindar dari perbuatan yang dilarang agama.

\section{KESIMPULAN:}

Peningkatan kasus dispensasi perkawinan setalah Undang-Undang Nomor 16 Tahun 2019 diundangkan di Pengadilan Agama Batusangkar disebabkan karena hamil di luar nikah, pergaulan bebas dan aktor ekonomi. Meningkatkatnya kasus dispensasi perkawinan berdampak pada hak-hak perempuan di bidang reproduksi, karena menikah pada usia muda. Oleh karena itu aturan dispensasi perkawinan perlu dikaji ulang karena belum menimbulkan efek jera dengan memberikan sanksi kepada pelaku dispensasi perkawinan

\section{REFERENSI:}

Al-Damasqy.. Tafsir Ibnu Katsir. Bayrut: Dar Al-Kutub AlIlmiyyah, 2004

Az-Zuhaili, Wahbah. Fiqih Islam Wa Adillatuhu. Terj. Abdul Hayyie al-Kattani, dkk. Cet 1. Jakarta: Gema Insani, 2011

Abdul Jalil. 2014. Fenomena Seksualitas Anak Muda vol 3 (jurnal) 
A. Rasyd, Roihan Hukum Acara

Peradilan Agama. Jakarta:

Raja Grafindo persada, 2005

Elimartati, Bunga Rampai Perkawinan di Indonesia. Batusangkar : STAIN Batusangkar Pers. 2014

Matlub, Abdul Majid Mahmud., Panduan Hukum Islam Keluaraga Sakinah. solo: Era Intermedia, 2005

Mustofa.. Perbandingan Hukum Perkawinan di Dunia Islam. Bandung: Pustaka Al-Fikriis. 2009

Maria Kabang dan Eli Trisnowati, Pemahaman Tentang Akibat Perkawinan Di Bawah Umur Melalui Layanan Informasi Dengan Teknik Diskusi , 2018, Vol 4 (Jurnal)

Syarif Maula, Bani, Jurnal Studi Islam Gender dan Anak, IAIN Purwekerto, 2019, volume 14 Nomor. 1

Tihami, Sohari Sahrani, Fiqih Munakahat: Kajian Fikih perkawinan Lengkap. Jakarta : Rajawali Press, 2009 